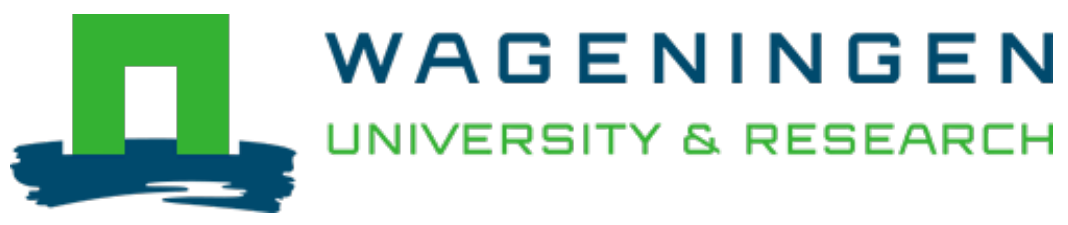

\author{
Degradation of cyanogenic glycosides of bitter apricot seeds (Prunus armeniaca) \\ by endogenous and added enzymes as affected by heat treatments and particle \\ size. \\ Food Chemistry \\ Tuncel, G.; Nout, M.J.R.; Brimer, L. \\ https://doi.org/10.1016/S0308-8146(97)00217-3
}

This publication is made publicly available in the institutional repository of Wageningen University and Research, under the terms of article $25 \mathrm{fa}$ of the Dutch Copyright Act, also known as the Amendment Taverne. This has been done with explicit consent by the author.

Article 25 fa states that the author of a short scientific work funded either wholly or partially by Dutch public funds is entitled to make that work publicly available for no consideration following a reasonable period of time after the work was first published, provided that clear reference is made to the source of the first publication of the work.

This publication is distributed under The Association of Universities in the Netherlands (VSNU) 'Article $25 \mathrm{fa}$ implementation' project. In this project research outputs of researchers employed by Dutch Universities that comply with the legal requirements of Article $25 \mathrm{fa}$ of the Dutch Copyright Act are distributed online and free of cost or other barriers in institutional repositories. Research outputs are distributed six months after their first online publication in the original published version and with proper attribution to the source of the original publication.

You are permitted to download and use the publication for personal purposes. All rights remain with the author(s) and / or copyright owner(s) of this work. Any use of the publication or parts of it other than authorised under article $25 \mathrm{fa}$ of the Dutch Copyright act is prohibited. Wageningen University \& Research and the author(s) of this publication shall not be held responsible or liable for any damages resulting from your (re)use of this publication.

For questions regarding the public availability of this publication please contact openscience.library@wur.nl 


\title{
Degradation of cyanogenic glycosides of bitter apricot seeds (Prunus armeniaca) by endogenous and added enzymes as affected by heat treatments and particle size
}

\author{
G. Tunçel, ${ }^{a}$ M. J. R. Nout, ${ }^{b *}$ \& L. Brimer \\ ${ }^{a}$ Food Engineering Department, Ege University, Bornova, Izmir, Turkey \\ ${ }^{b}$ Department of Food Technology and Nutritional Sciences, Agricultural University, Wageningen, The Netherlands \\ 'Department of Pharmacology and Pathobiology. Section of Pharmacology and Toxicology, Royal Veterinary and Agricultural University, \\ Copenhagen, Denmark
}

(Received 13 May 1997; revised version received 5 September 1997; accepted 15 September 1997)

\begin{abstract}
Bitter apricot (Prunus armeniaca) seeds (kernels) are by-products of the apricot processing industry. They contain approximately $50-150 \mu \mathrm{Mol} / \mathrm{g}$ (dry weight basis) of potentially toxic cyanogenic glycosides, mainly amygdalin and prunasin. The present paper deals with the degradation of these glycosides by endogenous and added enzymes in raw and blanched seeds of different particle sizes. A hot water blanching treatment of $20 \mathrm{~min}$ at $100^{\circ} \mathrm{C}$ was adequate to inactivate endogenous $\beta$-glucosidase activity in raw bitter apricot seeds. In addition to raw seeds, such blanched seeds were used as an experimental model to investigate the effect of particle size and added individual enzyme preparations on the degradation of cyanogenic glycosides. Finely ground $(<2 \mathrm{~mm}$ ) fractions showed increased glycoside degradation, supporting the hypothesis that particle size is a limiting factor for enzymic degradation. Our hypothesis that added pectinase activity would enhance degradation of glycosides by improving enzyme-substrate contact could not be affirmed. Furthermore, it was observed that substantial enzyme addition ( $\beta$-glucosidase) is required to fully degrade residual glycoside levels in raw and/or blanched seeds. (C) 1998 Elsevier Science Ltd. All rights reserved
\end{abstract}

\section{INTRODUCTION}

Bitter apricot (Prunus armeniaca) seeds (kernels) are by-products of the apricot processing industry. They are used as a substitute for bitter almonds to produce 'persipan' for the bakery industry. The oil ( $53 \%$ in the seed) is used, in e.g. cosmetics (Hallabo et al., 1975), as a cheaper substitute for bitter almond oil. The seeds can also be of interest as a food or feed ingredient because of their high crude protein content $(20-25 \% \mathrm{w} / \mathrm{w}$, dry weight basis). Bitter apricot seeds originate from the variety Prunus armeniaca var. amar (El-Adawy et al., 1994). However, depending on the specific cultivar (Femenia et al., 1995), they contain different concentrations of the potentially toxic (Lasch and $\mathrm{El}$ Shawa, 1981) amygdalin and prunasin. Thus, concentrations of approximately $50-150 \mu \mathrm{Mol} / \mathrm{g}$ (dry

*To whom correspondence should be addressed. Fax: +31$317-484893$. weight basis) have been reported (Abd El-Aal et al., 1986; Tunçel et al., 1990; Femenia et al., 1995). Degradation of these glycosidic cyanogens (GLY) will result in the formation of mandelonitrile and finally free $\mathrm{CN}^{-}$, both molecules being non-glycosidic cyanogens (NGC). We reported earlier (Tunçel et al., 1990) on prospects for detoxification by biotechnological means, i.e. by using the endogenous enzymes combined with microbial fermentation. The tempe fermentation process using the fungus Rhizopus oligosporus as inoculant enabled a removal of around $70 \%$ of total cyanide potential. As we considered this inadequate from a toxicological point of view, we screened different microbial strains for their ability to degrade amygdalin by hydrolysis. Some strains showed degradation activity $>95 \%$ of initial levels of amygdalin (Brimer et al., 1993; Nout et al., 1995).

On the other hand, results by Nout et al. (1995) and Tunçel et al. (1995) showed that endogenous $\beta$ glucosidase activity causes significant degradation of 
amygdalin in soaked ground seeds, and that the rate of degradation is increased when smaller particle sizes of apricot seed are used. In spite of great reductions, none of the wet seed products reach levels of total cyanogenic potential as low as those set for cassava flour and gari from cassava, not even after cooking (Tunçel et al., 1995).

The present paper addresses the question what factor(s) limit the efficacy of endogenous $\beta$-glucosidases in detoxifying apricot glycosides. Our hypothesis is that degradation of apricot seed cell walls is a major factor enabling contact between $\beta$-glucosidases and cyanogenic glycosides. This would explain the higher rate and extent of degradation when using smaller particle sizes. In addition, pectin-degrading enzymes might favour the action of $\beta$-glucosidases by improving the contact between substrate and enzymes.

The experiments were carried out with raw (non-blanched) as well as blanched seeds. The use of raw seeds with active endogenous $\beta$-glucosidases enables an assessment of the additional effect of microbial $\beta$-glucosidases and cell wall- and/or pectin-degrading enzymes. However, the study of the effect of an added enzyme, or enzyme mixture, on the degradation of the cyanogenic glycosides in ground tissues (e.g. seeds) is difficult. Thus, the level of endogenous $\beta$-glucosidase(s) may vary between seed batches, as may the degree of release of both these enzyme(s) and the glycosides during the comminution. In addition, crude microbiological preparations will contain a mixture of $\beta$-glucosidase(s), pectinase(s) and cellulase(s), of which the tissue and cell degrading enzymes will affect the above mentioned release further.

In order to study the effect of a number of crude microbiological preparations with considerable $\beta$-glucosidase activity as measured using amygdalin, the use of a simplified system was found to be essential. Hence for this purpose we used blanched seeds in which the endogenous enzyme activities had been inactivated, as a substrate.

\section{MATERIALS AND METHODS}

\section{Materials}

Bitter apricot seeds were obtained from Izmir, Turkey. Pectinase (EC 3.2.1.15) from Rhizopus sp. (P 2401) and $\beta$-glucosidase from almond (G-0395) were purchased from Sigma (St Louis, MO, USA). Olivex (batch G-509) was obtained from NOVO, Denmark. Picrate reagent sheets were prepared according to Brimer et al. (1983). Candida guilliermondii strain LU 120 (LU codes refer to the collection maintained at the laboratory of food microbiology, Agricultural University, Wageningen, The Netherlands), and Endomyces fibuliger LU677 originate from fermented foods. Aspergillus niger LU1500 was isolated by $\mathrm{G}$. Tunçel from Turkish soil.

\section{Seed processing}

Blanching conditions required to inactivate endogenous $\beta$-glucosidases were determined as follows: whole apricot seeds (portions of $100 \mathrm{~g}$ ) were wrapped in cheese cloth and blanched by immersion in boiling water for 5 , 10,20 or $30 \mathrm{~min}$; one portion was autoclaved at $121^{\circ} \mathrm{C}$ for $15 \mathrm{~min}$. The control group was not blanched. Seeds were ground in a kitchen cutter (Krups type $708 \mathrm{~A}$, Ireland). The particle size was determined using Karl Kolb (Germany) test sieves.

\section{Determination of blanching conditions}

Residual activity of $\beta$-glucosidases after heat treatments was assessed by comparison of levels of glycosidic and non-glycosidic cyanide in coarsely ground seeds immediately after heating, and after soaking $\left(25^{\circ} \mathrm{C}\right.$ for $2 \mathrm{~h}$ ), as follows: (a) $20 \mathrm{~g}$ coarsely ground heated seeds were extracted with $180 \mathrm{ml}$ of $0.1 \mathrm{M} \mathrm{H}_{3} \mathrm{PO}_{4}$; (b) $20 \mathrm{~g}$ coarsely ground heated seeds were soaked in beakers with $60 \mathrm{ml}$ of tap water at $25^{\circ} \mathrm{C}$ for $2 \mathrm{~h}$. Then the total content of beaker was poured into a coned paperfilter (Whatman ashless 41), and the filter cake and filter paper were extracted into $180 \mathrm{ml}$ of $0.1 \mathrm{M} \mathrm{H}_{3} \mathrm{PO}_{4}$.

\section{Cyanogen analysis}

All samples were analysed for total cyanogenic potential (GLY + NGC) and for non-glycosidic cyanogens (NGC), as described by Tunçel et al. (1995). From these results the content of cyanogenic glycosides (amygdalin + prunasin) was calculated. This result is reported as 'GLY'. Just prior to analysis, unstable working solutions were prepared from $5 \mathrm{ml}$ of the stable phosphoric acid homogenates, adding phosphate buffer $(0.1 \mathrm{M}$ $\left.\mathrm{Na}_{3} \mathrm{PO}_{4} / \mathrm{H}_{3} \mathrm{PO}_{4}, \mathrm{pH} 7\right)$ to give solutions with a resulting $\mathrm{pH}$ of 6.5 (dilution factor was noted). Calibration curves were produced by hydrolysis of aliquots of a $1 \mathrm{mM}$ aqueous solution of amygdalin, a $0.2 \% \mathrm{w} / \mathrm{v}$ solution of pectinase being used as source of hydrolytic enzymes for both standards and samples to be analysed for total cyanogenic potential (Brimer and Rosling, 1993). Sample hydrolysis was performed in microtitre plates (Brimer et al., 1993). Each well contained $1000 \mu \mathrm{l}$ of buffer $\mathrm{pH} 7+50,30,10$ or $5 \mu$ l supernatant of extract ( 2 wells/plate). One hundred microlitres of pectinase were added to half of the wells to measure cyanogenic potential. Plates were covered with picrate sheets and incubated at $25^{\circ} \mathrm{C}$ overnight. The density of the redbrown spots on a yellow background typical of positive reactions was assessed by measuring the relative colour intensity, expressed as $K / S$ (absorption/scatter) in arbitrary units, with a Nycocard Reader Model V 1.0 (manufactured by Nycomed Pharma AS, Norway). Calculations were expressed as $\mu \mathrm{mol} / \mathrm{g}$ fresh weight of seeds processed. The detection level was $1 \mu \mathrm{mol} \mathrm{HCN} / \mathrm{g}$ (Tunçel et al., 1995). Duplicate extractions were made 
of each treatment, and of each acidic homogenate, a dilution series was made and each dilution tested in duplicate wells.

\section{The influence of added enzyme preparations and particle size}

Raw and blanched seeds $\left(20 \mathrm{~min}\right.$ at $\left.100^{\circ} \mathrm{C}\right)$ were ground to obtain coarse $(2-4 \mathrm{~mm})$ and fine $(<2 \mathrm{~mm})$ fractions as described above. For both particle sizes the following treatments were applied: (A) immediate extraction ( $20 \mathrm{~g}$ fresh weight in $180 \mathrm{ml}$ of $0.1 \mathrm{M} \mathrm{H}_{3} \mathrm{PO}_{4}$ ); (B) $20 \mathrm{~g}$ fresh weight $+55 \mathrm{ml}$ water + supernatant (amygdalase activity $1.4 \mu \mathrm{mol} / \mathrm{h} / \mathrm{ml}$ ) of Candida guilliermondii strain LU120 grown for $72 \mathrm{~h}$ at $30^{\circ} \mathrm{C}$ in Malt Extract Broth, incubate $37^{\circ} \mathrm{C}$ for $3 \mathrm{~h}$, filter, extract in $180 \mathrm{ml}$ of $0.1 \mathrm{M} \mathrm{H}_{3} \mathrm{PO}_{4}$; (C) same, but with supernatant (act. $4.8 \mu \mathrm{mol} / \mathrm{h} / \mathrm{ml}$ ) of Endomyces fibuliger LU 677 grown for $72 \mathrm{~h}$ at $30^{\circ} \mathrm{C}$ in Malt Extract Broth; (D) same, but with supernatant (act. $67.4 \mu \mathrm{mol} / \mathrm{h} / \mathrm{ml}$ ) of Aspergillus niger LU1500 grown for $72 \mathrm{~h}$ at $30^{\circ} \mathrm{C}$ in Malt Extract Broth; (E) same, but with $0.3 \%$ Olivex (act. $0.8 \mu \mathrm{mol} / \mathrm{h} / \mathrm{ml}$ ); (F) same, but with $0.3 \% \beta$-glucosidase (act. $14.8 \mathrm{mmol} / \mathrm{h} / \mathrm{ml}$ ); (G) same, but with $\mathrm{mix}$ of Olivex $+\beta$-glucosidase, each of equal amygdalase activity; $H$ : same, but with $\operatorname{mix}$ of Olivex + supernatant LU1500 each of equal amygdalase activity.

Sample hydrolysis was performed in microtitre plates Each well contained $1000 \mu \mathrm{l}$ of buffer $\mathrm{pH} 7+50$ and $20 \mu 1$ supernatant of extract ( 2 wells/plate). One hundred microlitres of pectinase were added to half of the wells. Plates were covered with picrate sheets and incubated at $25^{\circ} \mathrm{C}$ overnight. Samples were analysed for total cyanogenic potential and for non-glycosidic cyanogens, as described above.

\section{RESULTS AND DISCUSSION}

The effect of blanching on degradation of cyanogenic glycosides (amygdalin + prunasin) by endogenous $\beta$ glycosidases is shown in Table 1 . Seed $\beta$-glucosidase activity causes significant degradation of cyanogenic glycosides in ground seeds without blanching (Tunçel $e t$ al., 1990; Nout et al., 1995). These plant enzymes gain access to the glucoside after physical disruption of the cell. They will act at about $20-40^{\circ} \mathrm{C}$ and are readily destroyed by heat. However, at this particle size ( 2 $4 \mathrm{~mm}$ ) the non-blanched seed fraction still had about $50 \%$ residual glycosides (Table 1 ); this shows the limited impact of endogenous $\beta$-glucosidases. In order to test the effects of a smaller particle size and of enzyme additions we decided to carry out part of the experiment in blanched seeds, thus eliminating the interference caused by the endogenous seed enzymes. We found that after the $20 \mathrm{~min}$ blanching treatment, endogenous activities had been stopped adequately, whereas suffcient residual cyanogenic glycosides were present in the
Table 1. The effect of hot water blanching on endogenous $\beta$ glucosidase activities in bitter apricot seeds (Prunus armeniaca)

\begin{tabular}{llccc}
\hline Heat treatment & \multicolumn{2}{l}{$\begin{array}{l}\text { Immediately after } \\
\text { heat treatment }\end{array}$} & $\begin{array}{c}\text { After } 2 \mathrm{~h} 25^{\circ} \mathrm{C} \text { soaking } \\
\text { of } 2-4 \mathrm{~mm} \text { fraction }\end{array}$ \\
\cline { 2 - 5 } & $\mathrm{GLY}^{a}$ & $\mathrm{NGC}^{a}$ & GLY & NGC \\
\hline None (raw seed) & $42 ; 37^{b}$ & $0 ; 0$ & $21 ; 20$ & $20 ; 23$ \\
$5 \mathrm{~min} 100^{\circ} \mathrm{C}$ & $20 ; 33$ & $0 ; 0$ & $7 ; 10$ & $16 ; 13$ \\
$10 \mathrm{~min} 100^{\circ} \mathrm{C}$ & $29 ; 23$ & $0 ; 0$ & $30 ; 25$ & $1 ; 0$ \\
$20 \mathrm{~min} 100^{\circ} \mathrm{C}$ & $29 ; 32$ & $0 ; 0$ & $27 ; 28$ & $0 ; 0$ \\
$30 \mathrm{~min} 100^{\circ} \mathrm{C}$ & $26 ; 31$ & $0 ; 0$ & $22 ; 32$ & $0 ; 0$ \\
$15 \mathrm{~min} 121^{\circ} \mathrm{C}$ & $19 ; 24$ & $0 ; 0$ & $18 ; 13$ & $0 ; 0$ \\
\hline
\end{tabular}

${ }^{a} \mathrm{GLY}=$ glycoside; NGC $=$ non-glycosidic cyanide.

${ }^{b}$ Data are of duplicate samples; $\mu \mathrm{mol} C N$ eq $/ \mathrm{g}$ seed fresh weight.

seeds to enable further degradation experiments. The general decrease in total recoverable cyanide is mainly due to diffusion to the blanching water.

Table 2 shows the effects of added enzyme preparations to seeds of different particle sizes, i.e. $2-4 \mathrm{~mm}$ and $<2 \mathrm{~mm}$ fractions. The reason for this experiment was to find out whether the cyanogen residue observed in nonblanched seeds could be reduced further in both types of seeds by the addition of enzymes. In the finely ground fraction, only blanched seeds were used as the endogenous enzyme activity in raw seeds would leave too little glycoside to achieve detectable degradation by the added enzymes. It was interesting to note that in raw seeds of $2-4 \mathrm{~mm}$ dimensions, only treatments $C$ and $F$ result in more degradation compared with the control as indicated by lower GLY and higher levels of NGC. The culture supernatants of LU120 and LU1500 did not give significantly increased degradation. We had expected a strong effect from Olivex that is used in the olive processing industry because of its high pectinase activities. Apparently, pectinases are not the enzymes required to stimulate glycoside release from apricot seeds. In blanched seeds of $2-4 \mathrm{~mm}$ particle size, only treatment $F$ gave complete degradation.

The question of particle size as a limiting factor was addressed using blanched seeds. Table 2 shows the effects of added enzyme preparations on coarse $(2-4 \mathrm{~mm})$ and fine $(<2 \mathrm{~mm})$ milling fractions of blanched apricot seeds. If finely ground seeds $(<2 \mathrm{~mm}$ ) were used, better enzymatic degradation could be obtained. The degradation of glycosides proved to be significantly $(p<0.05)$ more efficient in finely ground seeds. However, even in the fine grind most tested preparations yielded poor results (less than about $15 \%$ of total $\mathrm{CN}$ as NGC). Only at very high activity levels of $\beta$-glucosidase (Sigma) could it be shown that $100 \%$ conversion of GLY into NGC is possible. Combinations of $\beta$-glucosidase and Olivex (having high pectinase activity) as in treatment $G$ and $H$ again show that the effect of $\beta$-glucosidase is not enhanced by added pectolytic activity. These data would suggest that particle size is not the only critical factor. The substrate 
Table 2. Effect of particle size and added enzyme preparations on degradation of cyanogenic glycosides in apricot seeds (Prunus armeniaca)

\begin{tabular}{|c|c|c|c|c|c|c|c|c|c|}
\hline \multirow[t]{3}{*}{ Treatment } & \multirow[t]{3}{*}{$\begin{array}{l}\text { Enzyme } \\
\text { origin }\end{array}$} & \multirow{3}{*}{$\begin{array}{l}\text { Added amygdalase } \\
\text { activity }(\mu \mathrm{mol} / \mathrm{h} / \mathrm{g} \text { seed } \\
\text { fresh weight })\end{array}$} & \multirow[t]{3}{*}{$\begin{array}{c}\text { Incubation } \\
\left(\mathrm{h} /{ }^{\circ} \mathrm{C}\right)\end{array}$} & \multicolumn{4}{|c|}{$\begin{array}{l}\text { Coarse fraction } \\
\qquad(2-4 \mathrm{~mm})\end{array}$} & \multirow{2}{*}{\multicolumn{2}{|c|}{$\begin{array}{c}\begin{array}{c}\text { Fine fraction } \\
(<2 \mathrm{~mm})\end{array} \\
\begin{array}{c}\text { Blanched } \\
20 \mathrm{~min} 100^{\circ} \mathrm{C}\end{array}\end{array}$}} \\
\hline & & & & \multicolumn{2}{|c|}{$\begin{array}{c}\text { Raw } \\
\text { (non-blanched) }\end{array}$} & \multicolumn{2}{|c|}{$\begin{array}{c}\text { Blanched } \\
20 \mathrm{~min} 100^{\circ} \mathrm{C}\end{array}$} & & \\
\hline & & & & GLY $^{a}$ & $\mathrm{NGC}^{a}$ & GLY & NGC & GLY & NGC \\
\hline A & No addition & Not applicable & $3 / 37$ & $24 ; 27^{b}$ & $8 ; 11$ & $29 ; 32$ & $0 ; 0$ & $32 ; 31$ & $0 ; 0$ \\
\hline B & $\begin{array}{l}\text { LU120, } \\
\text { supernatant }\end{array}$ & 7 & $3 / 37$ & $26 ; 22$ & $11 ; 15$ & $30 ; 31$ & $0 ; 1$ & $30 ; 25$ & $2 ; 5$ \\
\hline $\mathrm{C}$ & $\begin{array}{l}\text { LU677, } \\
\text { supernatant }\end{array}$ & 24 & $3 / 37$ & $19 ; 17$ & $19 ; 20$ & $29 ; 28$ & $1 ; 1$ & $28 ; 24$ & $2 ; 7$ \\
\hline \multirow[t]{3}{*}{$\mathrm{D}$} & $\begin{array}{l}\text { LU1 } 1500, \\
\text { supernatant }\end{array}$ & 33.7 & $3 / 37$ & & & & & $30 ; 30$ & $0 ; 1$ \\
\hline & & 101.3 & & & & & & $29 ; 29$ & $1 ; 3$ \\
\hline & & 337 & & $24 ; 27$ & $13 ; 10$ & $31 ; 25$ & $0 ; 6$ & $29 ; 26$ & $3 ; 4$ \\
\hline \multirow[t]{3}{*}{$\mathrm{E}$} & $\begin{array}{l}\text { Olivex, } \\
\text { NOVO }\end{array}$ & 4 & $3 / 37$ & $29 ; 28$ & $11 ; 8$ & $28 ; 29$ & $2 ; 2$ & $27 ; 22$ & $3 ; 9$ \\
\hline & & 37.5 & & & & & & $28 ; 24$ & $3 ; 5$ \\
\hline & & 112.5 & & & & & & $26 ; 23$ & $4 ; 6$ \\
\hline \multirow[t]{2}{*}{$F$} & $\begin{array}{l}\beta \text {-Glucosidase, } \\
\text { Sigma }\end{array}$ & 37 & $3 / 37$ & & & & & $30 ; 28$ & $1 ; 2$ \\
\hline & & 111 & & & & & & $23 ; 22$ & $7 ; 10$ \\
\hline \multirow[t]{2}{*}{ G } & $\begin{array}{l}\text { Olivex }+ \\
\beta \text {-Glucosidase }\end{array}$ & $\begin{array}{c}74000 \\
37\end{array}$ & $3 / 37$ & $15 ; 16$ & $20 ; 18$ & $1 ; 1$ & $30 ; 32$ & $\begin{array}{c}0 ; 1 \\
30 ; 28\end{array}$ & $\begin{array}{c}29 ; 30 \\
1 ; 2\end{array}$ \\
\hline & & 112 & & & & & & $28 ; 27$ & $2 ; 2$ \\
\hline $\mathrm{H}$ & Olivex + LU1500 & $\begin{array}{c}34 \\
102\end{array}$ & $3 / 37$ & & & & & $31 ; 30$ & $0 ; 1$ \\
\hline
\end{tabular}

${ }^{a} \mathrm{GLY}=$ glycoside; NGC $=$ non-glycosidic cyanide.

${ }^{b}$ Data are of duplicate samples; $\mu \mathrm{mol} \mathrm{CN}$ eq/g seed fresh weight.

affinity of the tested enzymes is possibly inadequate, and other potential limitations (e.g. absence of other required cell wall-degrading enzymes, and/or feed-back inhibition) may play a role. A further study aimed at characterizing the kinetics of the enzymes discussed here could be helpful to understand the nature of the enzyme-related limitations of amygdalin degradation. Additional tests with a series of cell wall-degrading enzymes could be useful.

\section{ACKNOWLEDGEMENTS}

The technical contribution of Birgit Hasenack, Department of Food Technology and Nutritional Sciences, Agricultural University, Wageningen is gratefully acknowledged. This project was supported by NATO Collaborative Research Grant 920009.

\section{REFERENCES}

Abd El-Aal, M. H., Hamza, M. A. and Rahma, E. H. (1986) In vitro digestibility, physicochemical and functional properties of apricot kernel proteins. Food Chem. 19, 197-211.
Brimer, L., Brogger Christensen, S., Molgaard, P. and Nartey, F. (1983) Determination of cyanogenic compounds by thin layer chromatography. 1. A densitometric method for quantification of cyanogenic glycosides, employing enzyme preparations ( $\beta$-glucuronidase) from Helix pomatia and picrate-impregnated ion-exchange sheets. J. Agric. Food Chem. 31, 789-793.

Brimer, L. and Rosling, H. (1993) Microdiffusion method with solid state detection of cyanogenic glycosides from cassava in human urine. Food Chem. Toxicol. 31, 599-603.

Brimer, L., Tunçel, G. and Nout, M. J. R. (1993) Simple screening procedure for microorganisms to degrade amygdalin. Biotechnology Techniques 7, 683-687.

El-Adawy, T. A., Rahma, E. H., El-Badawey, A. A., Gomaa, M. A., Lasztity, R. and Sarkadi, L. (1994) Biochemical studies of some non-conventional sources of proteins. Part 7 . Effect of detoxification treatments on the nutritional quality of apricot kernels. Die Nahrung 38, 12-20.

Femenia, A., Rossello, C., Mulet, A. and Canellas, J. (1995) Chemical composition of bitter and sweet apricot kernels. $J$. Agric. Food Chem. 43, 356-361.

Hallabo, S. A. S., El-Wakeil, F. A., Morsi, M. and Khairy, S. (1975) Chemical and physical properties of apricot kernel oil and almond kernel oil. Egypt J. Food Sci. 3, 1-5.

Lasch, E. E. and El Shawa, R. (1981) Multiple cases of cyanide poisoning by apricot kernels in children from Gaza. Pediatrics 68, 5-7.

Nout, M. J. R., Tunçel, G. and Brimer, L. (1995) Microbial degradation of amygdalin of bitter apricot seeds (Prunus armeniaca). Int. J. Food Microbiol. 24, 407-412. 
Tunçel, G., Nout, M. J. R., Brimer, L. and Göktan, D. (1990) Toxicological, nutritional and microbiological evaluation of tempe fermentation with Rhizopus oligosporus of bitter and sweet apricot seeds. Int. J. Food Microbiol. 11, 337-344.
Tunçel, G., Nout, M. J. R. and Brimer, L. (1995) The effects of grinding, soaking and cooking on the degradation of amygdalin of bitter apricot seeds. Food Chem. 53, 447451 . 